\title{
Policy Instruments and Budgetary Processes: A Reflection on the Deficit Elimination Experience in the Canadian Provinces
}

\author{
Louis M. Imbeau \\ Centre d'Analyse des Politiques Publiques (CAPP), Département de Science Politique, Université Laval, \\ Québec City, Canada \\ Email: Louis.Imbeau@pol.ulaval.ca
}

Received 23 April 2014; revised 26 May 2014; accepted 17 June 2014

Copyright (C) 2014 by author and Scientific Research Publishing Inc.

This work is licensed under the Creative Commons Attribution International License (CC BY).

http://creativecommons.org/licenses/by/4.0/

(c) (i) Open Access

\begin{abstract}
Analyses of the deficit elimination experience in provincial governments in Canada in the 1990s show that provincial authorities used similar sets of policy measures to reach the goal of a balanced budget within a short period of time. We look at these measures as policy instruments and we try to make sense of their use through a theoretically informed reflection on the role of information and trust in the budgetary process. The principal-agent theory shows how the Premier and his team circumvented the problems caused by the information monopoly of managers through the implementation of a top-down process for setting budgetary targets and through the decentralisation of operational decision-making. However, this theory is completely silent concerning the use of rhetorical instruments. The convention theory suggests that regulatory and rhetorical measures were combined to influence guardians of the treasury and program advocates in their visions of the budget and thus changed the budgetary process from an incremental process to a fiscal crisis process. The same policy instruments take on a different meaning depending on the theoretical lens that one uses. Their use fosters identical outcomes (in this case, a balanced budget) through different paths. The knowledge of the process through which the use of a given policy instrument might lead to a given outcome is essential if we want to get a better grasp of the side effects of the use of any policy instruments.
\end{abstract}

\section{Keywords}

Policy Instruments, Fiscal Policy, Public Deficit, Canada, Principal-Agent Theory, Convention Theory 


\section{Introduction}

In 1992, after a series of negative evaluation by credit rating agencies, the government of the Canadian province of Saskatchewan was facing quasi-bankruptcy as it realised that it had important difficulties in finding the funds necessary to meet its borrowing requirements on the capital market. At that time, its credit rating was BBB. From this point on, the Saskatchewan government, soon imitated by other provincial and the federal governments, started a strict program aimed at balancing its operating budget, involving spending and tax instruments, as well as what seemed to be a coherent set of regulatory and rhetorical measures:

- Budget targets were imposed by the Premier or the Cabinet rather than "negotiated” by program ministers and the Treasury Board.

- A business planning approach to department budgeting was imposed to all departments and decisions about the operational decisions necessary to reach the target were decentralized.

- Anti-deficit legislations were adopted.

- Conferences, committees of the legislative assembly, review commissions, etc. were put together to "analyse" the situation, to consult various interested publics and to suggest solutions.

- A coherent discourse, based on the potentially negative impacts of budget deficits on economic growth and on their inequity vis-à-vis the next generations, was elaborated and presented in all sorts of forums ${ }^{1}$.

In other words, provincial authorities chose a set of policy instruments to ensure observance, cooperation and execution of their balanced budget policy.

Bruce Doern and Richard Phidd define policy instruments as "the major ways in which governments seek to ensure compliance, support and implementation of public policy” (Doern \& Phidd, 1983: 111)². For them, the main instruments available to governing authorities are: exhortation, expenditure, taxation, regulation and public enterprise”. The policy measures listed above fall in the categories of exhortation and regulation. But, as Doern and Phidd argue, policy instruments are not only “means” to foster “ends”, but they "are also 'ends' in themselves". "They are object of political dispute, are embedded with ideas and are valued because they fundamentally affect the process and content of policy making” (p. 111).

Focusing on the impact of policy instruments on the budgetary process, we propose in this paper to explore how two economic theories of the policy process may be useful to shed light on the way provincial authorities in Canada successfully eliminated their deficits in the 1990s. Indeed, one of the important breakthroughs of economic theory in recent decades has been to open the black box of government decision-making in order to free itself from the neo-classical assumption of a single actor government. Now several economic theories are available that take into account the fact that policy actors do not share the same preference ordering, that they do compete with each other to foster their own objectives, and that the outcome of the policy process does not necessarily correspond to the outcome of a rational process. In short, they accept the premise that the policy process is a political one. We will focus on two of these theories, the principal-agent theory and the convention theory ${ }^{3}$.

\section{The Principal-Agent Theory}

For the principal-agent theory, relations among actors in the policy process are typically principal-agent relations where one actor, the "principal”, delegates part of her responsibilities to an "agent" who controls information that is not accessible to the principal. The agent uses his monopoly over information in order to foster his own interests.

In the budgetary process the agent and the principal have divergent interests. The agent controls the information on budgets. Basically this information concerns: 1) his own behaviour, that is how he spends the money, how he sets his priorities; 2) the characteristics of the goods or services that his agency produces (real costs and benefits); 3) the slack that exists in the budget, or the discretionary budget (i.e. the proportion of the budget that can be cut without the services being jeopardized). For the agent, the less he reveals to the principal, the more power he has on her and the more efficiently he can maximize his budget (or protect it from erosion). Considering information as capital asset, the agent may accept to trade part of it for advantages that the principal would

\footnotetext{
${ }^{1}$ For an analysis of the deficit elimination process in Alberta, see (Bruce, Kneebone, \& McKenzie, 1997); in Québec see (Imbeau \& Leclerc, 2002). For a comparison of the deficit elimination experiences in the provinces of Saskatchewan, Alberta and British Columbia, see (Imbeau, 2000).

${ }^{2}$ For a review of the concept of policy instruments and its use in the public policy literature, see (Varone, 1998).

${ }^{3}$ Our review of these theories owes much to the excellent synthesis made by Sophie Béjean (1994).
} 
be willing to consent on him. Indeed, the principal needs to get as much information as possible from the agent in order to avoid three main problems: 1) moral hazards, that is the risk of having the agent follow an agenda that is different from her own, like resisting or sabotaging her chosen course of action; 2) adverse selection, that is the risk of choosing a wrong set of goods and services because of lack of information about the characteristics of these goods and services; 3 ) free riding, due to the agent using a higher budget than necessary.

If we apply the principal-agent model to the case of the deficit elimination policy, we see that the information provincial authorities (the principal) needed most in pursuing their goal was the discretionary budget that managers (the agent) had been able to create for themselves over the years. They also needed to know the characteristics of the services produced by government agencies, i.e. which ones were essential and which ones were not, so that they could better balance budget cuts among departments and services. Managers had an interest in concealing the information concerning their discretionary margin and, therefore, in artificially inflating their estimated needs and costs.

The depiction of the interaction between the principal and the agent in a game theory format shows how a combination of strategies (or choice of instruments) may have an effect on the budgetary process.

Let the agent be the column player and let the principal be the row player. Let us define the agent's strategies as transparency or opacity. The benefits of transparency to the agent is the trust that he can accumulate with the principal in the hope that it will pay off in the future, as proposed by the theory of informal transactions (Wintrobe \& Breton, 1986). Benefits can also be derived from bonuses that the principal may attach to that type of behaviour. However the strategy of transparency costs the agent a decrease in control over the agenda. Let us now define the principal's strategies as coercion or incentive. The benefits of coercion over incentive are simplicity and rapidity. It is simpler and faster to demand than to convince. But coercion may impose higher monitoring costs needed to enforce the decision. The combination of these strategies yields four outcomes, i.e., typical budgetary processes: a bottom-up process when the agent conceals information and the principal tries to convince him not to; a top-down process in the opposite situation where the principal demands and the agent complies; a cooperative process when both players cooperate; and a hybrid process, "decentralized top-down" process where both actors keep their autonomy (Figure 1). Because of the costs and benefits they get from each outcome, the principal and the agent have different preference orderings:

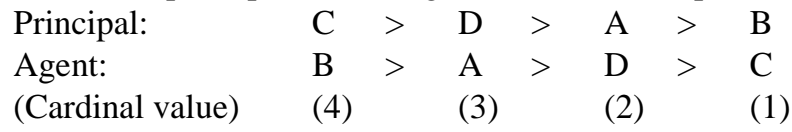

Given these choices of strategy and these preference orderings, we have a game whose natural solution is D (Decentralized top-down process) since both players have a dominant strategy (coercion for the principal and opacity for the agent). The principal is the favoured player since the outcome is higher on her preference scale than it is on the agent's.

Let us now return to the issue of policy instruments. If we conceive the choice of a policy instrument by governing authorities and managers as the equivalent of the choice of a strategy in the principal-agent game depicted above, we see that the choice of policy instruments by the actors have an impact on the nature of the budgetary process. The top-down process, for example, is one where the principal succeeded in forcing the agent to divulge the information he has. Even more interesting, we see that the decisions made by provincial governments to impose budgetary target and to let managers find their own way to them corresponds to the natural solution of the interaction between an agent who conceals information from a principal who has a tendency to impose constraints rather than use incentives. What is interesting here is that the game theoretic solution corre-

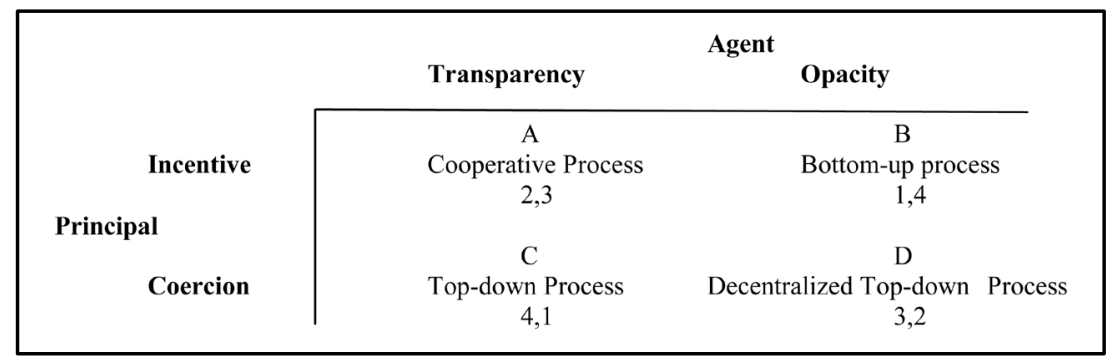

Figure 1. The principal-agent budgetary relationship in the budgetary process. 
sponds to the actual solution provincial authorities found to the fundamental problem revealed by the theory, that of the information monopoly in favour of managers in the policy making process. By centralizing the decisions over the objectives and by decentralizing the decisions over the means, provincial authorities freed themselves from the principal's dependence on the information monopoly of the agent.

However, despite its unequivocal qualities, the principal-agent theory tells us nothing about the use of rhetorical instruments which it considers irrelevant even though these instruments were central in the process of eliminating the deficit. If we want to make theoretical sense of the use of rhetorical instruments in this process, we must look for another theory, the convention theory.

\section{The Convention Theory}

French economists working in the field of health services have coined the term Convention Theory (théorie des conventions (Béjean, 1994)) to refer to a body of theoretical explorations that follow the Principal-Agent theory in that they "open the black box" of government decision-making, but that depart from this theory and from mainstream economics in an important way: the assumption of maximizing rationality (rationalité substantielle) is relaxed in favour of an assumption of bounded rationality (March \& Simon with Guetzkow 1959; Simon 1978). The actor conceived by the conventionalist approach is neither the homo sociologicus whose behaviour is completely determined by norms and customs integrated in the socialization process, nor the homo oeconomicus who is motivated only by the maximization of some utility. His behaviour is guided by "convention-rules", that is systems of reciprocal expectations about competences and behaviour. In this context conventions are metarules, some explicit and codified, some implicit and spontaneous, that are elaborated in a long process of interaction among actors within an organization and are used as a collective cognitive mechanism allowing a saving of knowledge. Because of the flux of information that submerge the members of an organisation, and because actors have limited cognitive capacities, convention-rules are developed to simplify information processing through the elaboration of routines codifying behaviours and the definition of roles as the basis for the division of labour among the members of an organisation.

This idea of role playing in the budgetary process has been familiar to us since the work of Wildavsky (1964, 1975, 1988). Indeed, Wildavsky's model is a convention theory of the budgetary process. The budgetary convention regulates the relationship between the actors involved in the budgetary process within an organisation. It defines two roles that are the basis of a division of budgetary responsibilities: guardians of the treasury and program advocates. Guardians look after the whole budget to make sure that budgetary allocations respect the rules of the organization, in particular, the rules concerning deficits. When caring for the treasury, guardians do not worry about specific programs because they trust that advocates will do so. Indeed, advocates care mainly about the quality and the quantity of services offered under their responsibility and set their budgetary requests accordingly, without caring much about the whole of the budget since they know guardians take on this responsibility. Guardians and advocates interact in a complementary way thus creating a stable pattern of mutual expectations which tend to reduce the burden of calculations for budget participants. Trust is central in the interaction between guardians and advocates. It builds up over the long run through a process of learning. Without trust, guardians would impose stringent controls, thus encouraging the advocates' evasion to other sources of financing. Without trust, advocates may indulge in gross over-evaluations of their needs to secure the minimum for their service thus encouraging guardians to impose even more severe controls. In summary, the budgetary convention includes a division of responsibilities between guardians and advocates as well as control mechanisms and sanctions aimed at dissuading potential abuse. As long as there is trust between guardians and advocates, the organisation saves the cost of non-cooperation (cost of additional controls for guardians, cost of lobbying and of search for alternative sources of funds for advocates).

The guardian-advocate dynamics normally leads to incremental budgeting with positive or negative changes at the margin. This is, of course, far from what we observed in Canada in the deficit elimination period when spending decreased by an important measure each of several consecutive years. How can a convention theory account for the use provincial governments made of budget rules and rhetorical instruments?

The distribution of budgetary roles in the budgetary process in Canada is not all that clear. Generally, actors from central agencies (Finance, Treasury board) are seen as guardians whereas actors from program departments are considered as advocates (Savoie, 1990). However, the role of the Prime minister at the federal level or of the provincial Premiers is not clear. They are neither guardians nor advocates since these roles are linked to institu- 
tional positions outside the premier's office. But they can use regulatory and rhetorical instruments to influence the budgetary outcome. How is this done? Bounded rationality implies that, in addition to his or her role (i.e. the expected behaviour attached to one's institutional position), an actor's choice depends on the "decision premise", or attitude, active at the moment of choice. Here is how Nicholas Henry defines a decision premise:

A decision premise refers to the values and perceptions held by each member of the organization, on which he or she bases every decision made regarding the organization. These individual values and perceptions are unique to the individual, but many can be altered and influenced through the use of organizational means and sanctions available to those in positions of control, the division of labor in the organization and how it affects the individual, standard operating procedures used in the organizations, the socialization and training of new members of the organization, and the kinds of people who are selected to join the organization. Together, these techniques can mold each individual's decision premise in a way that reduces organizational uncertainty by making the individual's decisions predictable. When uncertainty is low [...], authority and control often are relinquished or “decentralized” (Henry, 1999: pp. 96-97).

In other words, even though roles are given by the institutional position occupied by an actor, this actor's attitude toward his role may vary.

Let us characterize the budgetary decision premises in two different attitudes regarding the budget: to favour a partial view of the budget or to favour a total view. In our context, favouring a partial view of the budget means supporting spending in a sector of government intervention (program, department, etc.); favouring a total view of the budget implies a particular attachment to the bottom line (deficit or surplus). In other words an actor may or may not have the attitude that perfectly corresponds to his role in the budgetary process. Role and attitudes are distinct. The combination of roles and attitudes defines four types of budgetary processes (Figure 2).

- Type 1, "Incremental Budgeting" occurs when attitudes correspond to roles: Guardians adopt a total view and advocates a partial view of the budget. This is the situation described by Wildavsky in the US and by Savoie in Canada where budgeting is done through small changes at the margin.

- Type 2, "Fiscal crisis budgeting" is the process that occurs when both advocates and guardians adopt a total view of the budget. They are more concerned with the whole of the budget than with the maintenance of programs.

- Type 3, "Social crisis budgeting" is the process characterized by both advocates and guardians adopting a partial vision of the budget. War budgets are made through that type of a process, most people in the process being mainly concerned with one program, the support of the war effort.

- Type 4, "Reversed Role Budgeting", corresponds to the situation where advocates adopt a total view and guardians a partial view of the budget. For example advocates often act as guardians when, noting the interdependency of programs between ministries or departments, they indicate where funds could be saved in other ministries. Another illustration of this process when savings measures suggested by advocates to meet a budget target are more aggressive than what guardians are willing to tolerate. In this case, it becomes the responsibility of the central agency to come up with innovative solution.

This model makes explicit the way the combined use of regulatory and rhetorical instruments in the deficit elimination process impacted on the budgetary process and contributed to the realization of the balanced budget objective. Once they had decided that deficit elimination would be attained through severe spending cuts, provincial authorities started a campaign of rhetorical and regulatory measures that had the effect of reinforcing guardians in their total vision of the budget and of convincing advocates to adopt a total view. The imposition of precise budgetary targets and the decentralisation of operational budget decisions had exactly this impact: program managers where now responsible for reaching government's budget targets. The anti-deficit laws served as an additional argument to convince advocates that the government would not back down on its target. The impact of the discourse on inefficiency in public service, increased controls to counter tax evasion, intergenerational equity, etc. had the additional effect of convincing advocates to care about the whole budget. In summary, government interventions in budget rules and discourse introduced a change in the budgetary process which made it possible successfully to implement its balanced budget policy.

A conventionalist approach to deficit elimination shows how trust and learning in provincial public administration were central in the success of the balanced budget policy. Government regulatory and rhetorical interventions had an impact on public managers' attitudes towards the budget and therefore on their willingness to implement government objectives. 


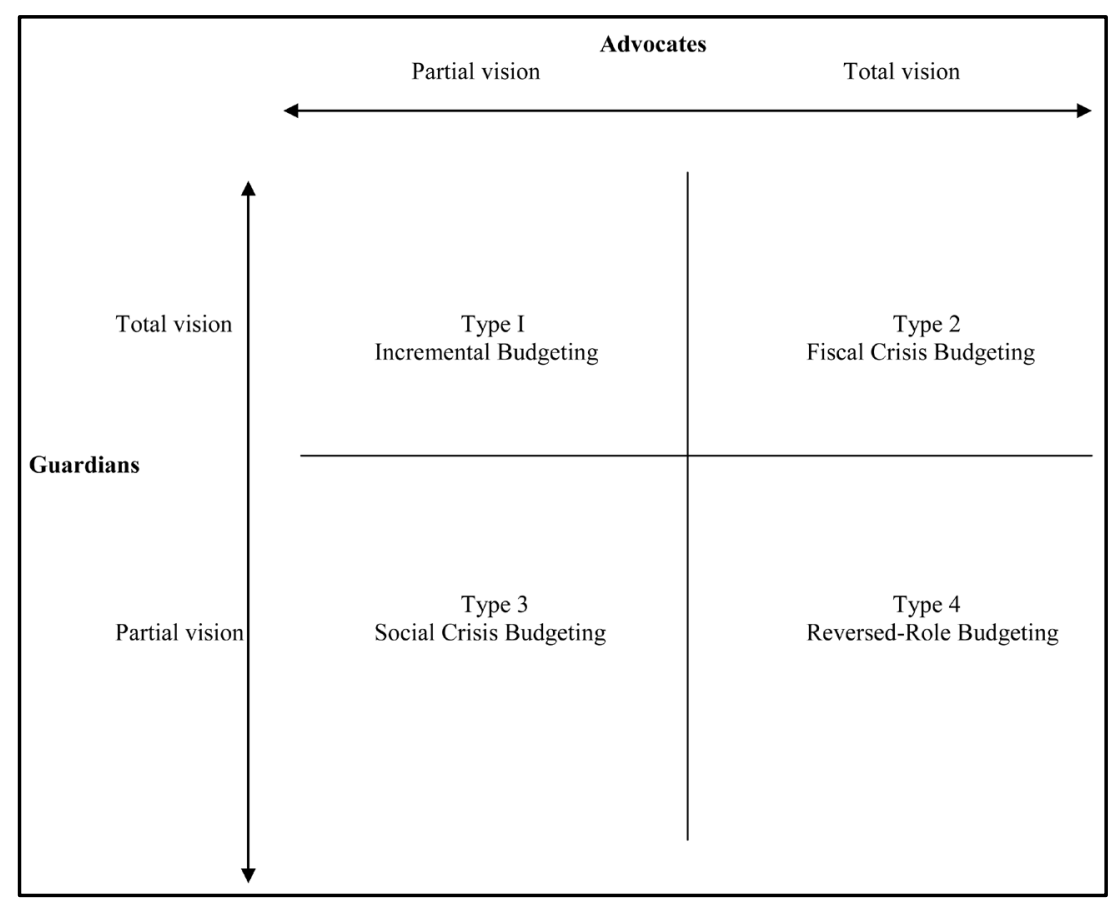

Figure 2. A model of budgetary processes based on roles (guardians or advocates) and attitudes (partial or total vision of the budget).

\section{Conclusion}

Policy instruments are not only means towards ends, but means towards processes towards ends. Between the course of action chosen to pursue a specific goal and its end-result lies the world of the policy process which may be affected by the policy instrument chosen. The conclusion one reaches about the effect of a given policy instrument on the policy process depends on the underlying theoretical model.

From a principal-agent perspective, changes in the budgetary rules made by provincial authorities in their attempt to eliminate their deficits through spending cuts modified the budgetary process in such a way that they could free themselves from their dependence on the information monopoly of public managers. Therefore the principal-agent theory may be useful to understand the impact of regulatory instruments on budgetary processes but it says nothing about the impact of rhetorical instruments which were central in the provincial governments' efforts to eliminate their deficits.

A conventionalist perspective integrates both regulatory and rhetorical instruments and provides a coherent description of the impact of these instruments on the budgetary process. The interaction between budget roles and budget attitudes that this approach puts to light shows how the use of regulatory and rhetorical instruments can be combined to affect the budgetary process in such a way as to increase the probability of success of a deficit elimination policy.

The same policy instruments take on a different meaning depending on the theoretical lens that one employs. Their use fosters identical outcomes (in this case, a balanced budget) through different paths. The knowledge of the process through which the use of a given policy instrument might lead to a given outcome is essential if we want to get a better grasp of the side effects of the use of any policy instruments.

\section{References}

Béjean, S. (1994). Économie du système de santé: Du marché à l'organisation. Paris: Economica.

Bruce, C. et al. (1997). A Government Reinvented: A Study of Alberta's Deficit Elimination Program. Toronto: Oxford University Press.

Doern, B. G., \& Phidd, R. W. (1983). Canadian Public Policy: Ideas, Structure, Process. Toronto: Methuen.

Henry, N. (1999). Public Administration and Public Affairs. Upper Saddle River, NJ: Prentice Hall. 
Imbeau, L. M. (2000). Guardians and Advocates in Deficit Elimination: Government Intervention in the Budgetary Process in Three Canadian Provinces. In J. Kleist, \& S. Huffman (Eds.), Canada Observed: Perspectives from Abroad and from Within (pp. 145-156). New York: Peter Lang.

Imbeau, L. M., \& Leclerc, M. (2002). L'élimination du déficit budgétaire au Québec: Contexte et réalisation d'un engagementélectoral. In F. Pétry (Ed.), Les engagements électoraux du parti québécois. Québec: Presses de l’Université Laval.

Savoie, D. J. (1990). The Politics of Public Spending in Canada. Toronto: University of Toronto Press.

Varone, F. (1998). Les choix des instruments des politiques publiques. Bern: Haupt.

Wildavsky, A. (1964). The Politics of the Budgetary Process. Toronto: Little, Brown and Co.

Wildavsky, A. (1975). Budgeting: A Comparative Theory of Budgetary Processes. Boston/Toronto: Little, Brown \& Company.

Wildavsky, A. (1988). The New Politics of the Budgetary Process. New York: Harper Collins Publishers.

Wintrobe, R., \& Breton, A. (1986). Organizational Structure and Productivity. The American Economic Review, 76, 530-538. 
Scientific Research Publishing (SCIRP) is one of the largest Open Access journal publishers. It is currently publishing more than 200 open access, online, peer-reviewed journals covering a wide range of academic disciplines. SCIRP serves the worldwide academic communities and contributes to the progress and application of science with its publication.

Other selected journals from SCIRP are listed as below. Submit your manuscript to us via either submit@scirp.org or Online Submission Portal.
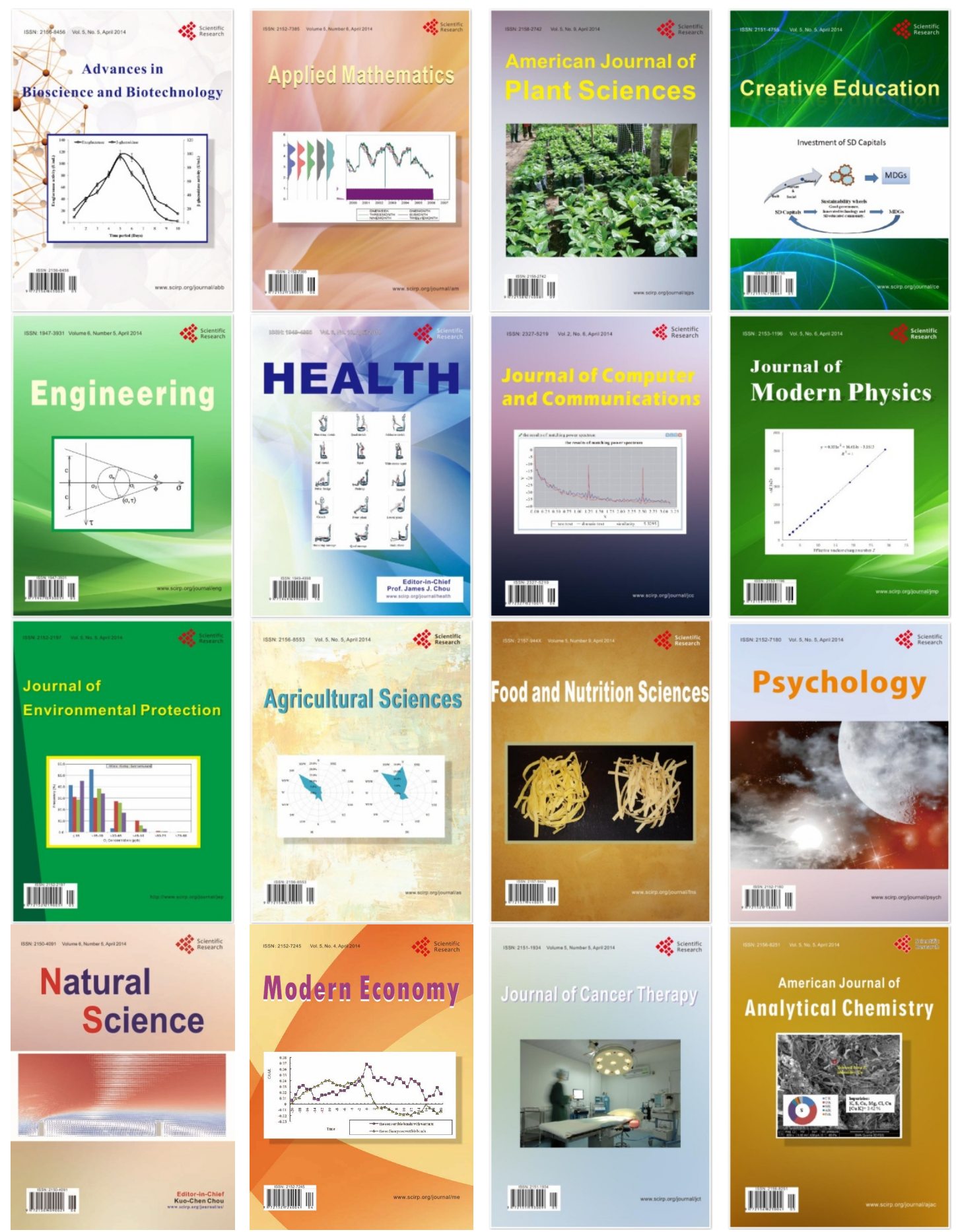